\title{
Review
}

\section{Friendship reconsidered: What it means and how it matters to politics}

\author{
P. E. Digeser \\ Columbia University Press, New York, 2016, xxi+361 pp., \\ ISBN: 978-0231174343
}

Contemporary Political Theory (2018) 17, S106-S109. https://doi.org/10.1057/s41296017-0121-3; published online 13 June 2017

Friendship Reconsidered is a welcome and original contribution to the literature exploring the connection between friendship and politics. There has been a growing interest in the topic in the last two decades. While scholars began to rediscover friendship, skepticism about the utility of the concept for understanding politics emerged in various quarters. In addressing several skeptical arguments and pitfalls in the existing research on friendship, P. E. Digeser takes the debate one step forward.

This book engages with important assumptions about friendship, and the author makes a laudable move by proposing to see friendship through the lens of 'family resemblances': friendship refers to a variety of practices that are not identical across time and space. She builds on insights from Ludwig Wittgenstein and Michael Oakeshott so as to avoid the painstaking job of supplying a definition that could encompass the cultural and historical heterogeneity of the human experience of friendship. However, Digeser offers several criteria for distinguishing friendship from cognate political relations. She argues that there must be a mutual recognition of appropriate motivations between friends and that friends 'subscribe to a shared set of adverbial conditions that structure how they act toward one another' (p. 51).

The book is divided in three parts. The first culminates in a theory of individuality suggesting that friendship should foster the self-enactment of friends. Digeser separately considers self-interest in friendship and concludes that utility could be a reason for friendship but this reason is deficient. The same goes for the duties of friendship, which are not unthinkable, but should be seen only as add-ons to the 'appropriate' reasons for friendship (p. 69). This suggestion echoes numerous commentaries on Aristotle, which tend to focus on what he considered to be the perfect type of friendship, i.e., 'the friendship of virtue.' Similarly, Digeser's 'ideal' is the 'bridging/bonding friendship,' in which a friend is attracted by another's individuality, by love of the other's self. In contrast to Aristotle, Digeser chooses the term 'character' to describe what underpins friends' attraction to each

(C) 2017 Macmillan Publishers Ltd. 1470-8914 Contemporary Political Theory Vol. 17, S2, S106-S109 
other (p. 95). In such friendships, it is the character and the enactment of individuality that forge and foster the relationship.

Having formulated this rather demanding ideal of friendship, she moves on to the second part of the book, which deals with the role of friendship in politics. She starts by confronting the popular idea of civic friendship articulated, inter alia, in Sibyl Schwarzenbach's On Civic Friendship: Including Women in the State (2009), also published by Columbia University Press. Digeser takes issue with the view of civic friendship as a model for citizenship. The main arguments for this view, as she demonstrates, are ultimately based either on the presumption that our fellowcitizens act out of friendship or on the confusion of friendship with civic virtue. The bottom-line is that these arguments fail to integrate the demand for the mutual recognition of motivations in friendship. In large modern societies, as Digeser argues, it is inconceivable that citizens would be capable of recognizing the motivations of fellow-citizens, whom they do not even know. Therefore, arguments for civic friendship mistake 'civility' and 'friendliness' between fellow-citizens for friendship (pp. 110-111). The problem with imagining friendship among citizens does not lie exclusively with the challenging task of recognizing multiple motivations. It emerges from the fact that the recognition, as Digeser sees it, should be mutual: a specific self recognizes the motives of the specific other, and this other reciprocates, making the process genuinely dyadic (p. 114).

The recognition of mutual motivations thus sets a limit to the scope of friendship. Yet friendship is possible in politics. Digeser illustrates this possibility using several examples, including Cornelius Nepos's biography of Atticus, central to the argument of the book. What Digeser portrays for us can at best be called 'islands of friendship' rather than national communities of friendship (p. 126). The type of friendship Digeser recognizes as political can cross partisan divides, but this seems to happen only among individuals who already share mutual bonds. Thus, civic friendship offers at best an ideal of citizenship, not a model for it (p. 142).

The discussion of international friendship in the third part stands out somewhat in the structure of the book. Digeser firmly argues that international friendship cannot be modeled on interpersonal friendship. Therefore, many of the requirements for interpersonal friendship do not apply to international friendship. International friendship has been a hard case for the emerging friendship studies, precisely because of the apparent incommensurability between interpersonal and interstate friendships. Many forms of interstate relations have thus been dismissed as incomplete friendships, friendships in word but not in deed, or mere alliances.

The strength of Digeser's book lies with her perspective on international friendship, at the center of which she places 'minimally just institutions.' In this realm of social relations, the emphasis shifts away from what agents do, i.e., mutually recognize motivations, to who the agents are and the character of those who are capable of friendship (p. 219). The concern for the character of states is in the interest of citizens, who, we are told, tend to support institutions that are just.

(C) 2017 Macmillan Publishers Ltd. 1470-8914 Contemporary Political Theory Vol. 17, S2, S106-S109 S107 
Therefore, states constituted by just institutions will be motivated to care for similar institutions in other states. If this motivation is reciprocated by other states which meet the standard of minimally just institutions, friendship of character may emerge (pp. 235-236).

This position allows Digeser to achieve two critical goals in the debate on international friendship. First, her account ostensibly helps distinguish international friendship from alliances and other partnerships. Second, the focus on institutions breaks away from understanding international friendship in affective terms (Eznack and Koschut, 2014).

Yet, this is where the book's weakness becomes apparent. Digeser's interpretation suggests friendship is dependent on the internal institutional arrangement of a state. This injects strong ideological commitments into her account. Digeser's friendships of character, similarly to friendships between individuals, would not be driven by utility, even though this motive is not dismissed completely (p. 274). In a nutshell, idealized friendships of character cover rather well-known and unsurprising friendships among a select number of western liberal democracies. The normative understanding of true friendship intentionally and complacently ignores friendships developing between deeply unjust regimes or regimes whose justness is hard to gauge. The definition of what is just, as Digeser concedes in passing ( $p$. 269), will remain a matter of political decision.

Moreover, the introduction of institutional character of a state as a factor in friendship sits uncomfortably with the practice-oriented approach professed at the beginning of the book. Genuine commitment to a family-resemblance and adverbial conditions of friendship cannot but help us notice that friendship in the history of international politics is not limited to friends of a particular character. Given that friendship, perhaps, is one of the oldest, if not the oldest, diplomatic instruments, it may be fruitful to give diplomacy - as knowledge and experience - a fairer share in our analysis of international friendship. When confronted with the variety and number of friendships in the world of states, this ideal friendship of character will perhaps appear too restrictive to make sense of friendships entered into for commercial advantage, territorial expansion, or affirming international hierarchies. All these forms of friendship are familiar to us from the history of imperialism, international trade, and construction of regional blocs, but they fall outside Digeser's account.

Although sympathetic to the longing for a world politics based on justice and cooperation, I am convinced that no single definition or requirement - such as concern for minimally just institutions - could offer a coherent vision of friendship between states, and of politics more broadly. Practice-oriented approaches, only partially embraced by Digeser, should pay more attention to what agents, be they states or individuals, call friendship, what makes such speech-acts conventional, i.e., what ensures their uptake by the audience, and how these agents act as friends. This requires facing a probably inconvenient political reality, in which the motive 
of utility is as sufficient for friendship as the concern for the character of the other. Discarding concerns for obligations, contracts, and inequalities restricts our vision of the politics of friendship, rendering it even narrower than Aristotle's canonical version.

\section{References}

Eznack, L., \& Koschut, S. (2014). The Sources of Affect in Interstate Friendship. In Simon Koschut \& Andrea Oelsner (Eds.), Friendship and International Relations (pp. 72-88). Basingstoke and New York: Palgrave Macmillan.

Schwarzenbach, S. (2009). On Civic Friendship: Including Women in the State. New York: Columbia University Press.

Evgeny Roshchin

Department of comparative political studies, Russian Presidential Academy of National Economy and Public Administration, St Petersburg, Russia 199178 roshchin-en@sziu.ranepa.ru 